Ocena stomatologiczna i ortodontyczna dzieci i młodzieży ze Spektrum Płodowych Zaburzeń Alkoholowych (FASD) przegląd piśmiennictwa

\section{Dental and orthodontic evaluation of children and adolescents with Foetal Alcohol Spectrum Disorders (FASD) - a review of the literature}

\author{
Katarzyna Ludwików ABD (ORCID ID: 0000-0003-3422-7038) \\ Małgorzata Zadurska EF (ORCID ID: 0000-0002-2303-4102) \\ Ewa Czochrowska AEF (ORCID ID: 0000-0003-1009-6483)
}

\begin{abstract}
Wkład autorów: $\mathbf{A}$ Plan badań $\mathbf{B}$ Zbieranie danych $\mathbf{C}$ Analiza statystyczna $\mathbf{D}$ Interpretacja danych $\mathbf{E}$ Redagowanie pracy $\mathbf{F}$ Wyszukiwanie piśmiennictwa

Authors' Contribution: A Study design B Data Collection $\mathbf{C}$ Statistical Analysis $\mathbf{D}$ Data Interpretation E Manuscript Preparation $\mathbf{F}$ Literature Search
\end{abstract}

Zakład Ortodoncji, Warszawski Uniwersytet Medyczny Department of Orthodontics, Medical University of Warsaw

\begin{abstract}
Streszczenie
Spektrum Płodowych Zaburzeń Alkoholowych (Fetal Alcohol Syndrome Disorders, FASD) jest grupą nieuleczalnych nieprawidłowości rozwojowych u osób, których matki piły alkohol w trakcie ciąży. Najcięższą postacią z całego spektrum zaburzeń FASD jest Alkoholowy Zespół Płodowy (Fetal Alcohol Syndrome, FAS), a jedną z cech charakterystycznych są anomalie w budowie twarzoczaszki. Cel. Celem pracy była ocena stanu zdrowia jamy ustnej oraz występowania wad zgryzu i potrzeb leczenia ortodontycznego u dzieci z FASD na podstawie analizy piśmiennictwa. Materiał i metody. Przeprowadzono przegląd piśmiennictwa w oparciu o bazy danych: PubMed, Scopus, Dentistry \& Oral Sciences Source,
\end{abstract}

\begin{abstract}
Foetal Alcohol Syndrome Disorders (FASD) are a group of untreatable developmental abnormalities in people whose mothers consumed alcohol during pregnancy. Foetal Alcohol Syndrome (FAS) is the most severe form of the entire spectrum of disorders and anomalies in the craniofacial structure are among its defining features. Aim. The aim of the study was to assess oral health and the occurrence of malocclusions as well as the need for orthodontic treatment in children with FASD based on the available literature. Material and methods. A literature review based on the following databases was conducted: PubMed, Scopus, Dentistry \& Oral Sciences Source, Polish Medical Bibliography, and
\end{abstract}

Adres do korespondencji/Correspondence address:

Katarzyna Ludwików

Zakład Ortodoncji, Warszawski Uniwersytet Medyczny

ul. Binieckiego 6, 00-097 Warszawa

email: katarzynaludwikow@gmail.com

\title{
@(1)@(2)
}

Copyright: (C) 2005 Polish Orthodontic Society. This is an Open Access journal, all articles are distributed under the terms of the Creative Commons Attribution-NonCommercial-ShareAlike 4.0 International (CC BY-NC-SA 4.0) License (http://creativecommons.org/licenses/by-nc-sa/4.0/), allowing third parties to copy and redistribute the material in any medium or format and to remix, transform, and build upon the material, provided the original work is properly cited and states its license. 
Polska Bibliografia Lekarska, z wykorzystaniem słów kluczowych FASD, fetal alcohol syndrome, facial abnormalities, prenatal alcohol exposure. Do analizy wybrano 35 artykułów z lat 1968-2020 w językach polskim i angielskim. Wyniki. U dzieci i młodzieży z FASD poziom higieny jamy ustnej jest niezadawalający. Obserwuje się większy wskaźnik próchnicy oraz więcej wad zgryzu, w porównaniu z populacją ogólną. Do głównych należą wady zgryzu klasy II, zgryzy krzyżowe oraz stłoczenia zębów. U dzieci z FASD występuje znacznie więcej dysfunkcji i parafunkcji w układzie stomatognatycznym. Wniosek. Dzieci z FASD powinny zostać objęte instytucjonalną opieką profilaktyczną i leczniczą, która pozwoli na systematyczne kontrolowanie stanu zdrowia jamy ustnej i występujących wad zgryzu. (Ludwików K, Zadurska M, Czochrowska E. Ocena stomatologiczna i ortodontyczna dzieci i młodzieży ze Spektrum Płodowych Zaburzeń Alkoholowych (FASD) - przegląd piśmiennictwa. Forum Ortod 2021; 17 (3): 237-44).

Nadesłano: 30.08.2021

Przyjęto do druku: 29.10.2021

https://doi.org/10.5114/for.2021.11050

Słowa kluczowe: alkoholowy zespół płodowy, FAS, dysmorfia twarzy, prenatalna ekspozycja płodu na alkohol

\section{Wstęp}

FASD (Fetal Alcohol Spectrum Disorders - Spektrum Płodowych Zaburzeń Alkoholowych) jest terminem obejmującym wiele nieprawidłowości rozwojowych wynikających z prenatalnej ekspozycji na alkohol, natomiast FAS (Fetal Alcohol Syndrome) jest najcięższą jego formą i stanowi około $10 \%$ wszystkich zaburzeń z całej grupy FASD (1). Jako odrębna jednostka chorobowa FAS został opisany po raz pierwszy przez Lemoine i wsp. (2), a Jones i wsp. opisali pełne cechy dysmorficzne twarzy i zdefiniowali je jako alkoholowy zespół płodowy (3). Do cech klinicznych Alkoholowego Zespołu Płodowego należą:

1. nieprawidłowości w budowie głowy i szyi, tj. małogłowie, krótka szyja, nisko, asymetrycznie osadzone uszy, zniekształcone małżowiny uszne, niskie czoło, retrognatia i retrogenia, płaskie środkowe piętro twarzy, wąskie szczeliny powiekowe, szeroko rozstawione oczy, zmarszczka nakątna, krótki i mały nos, długa górna warga $\mathrm{z}$ wąską granicą czerwieni wargowej oraz spłycona lub nieobecna rynienka podnosowa,

2. uszkodzenia centralnego układu nerwowego,

3. niedobór wzrostu i wagi,

4. zaburzenia rozwojowe układów krążenia i kostnego (3).

Diagnostyka zespołu FAS może być problematyczna ze względu na heterogenny charakter zaburzenia i różnicowania cech the following keywords were used: FASD, fetal alcohol syndrome, facial abnormalities, prenatal alcohol exposure. 35 articles from the years 1968-2020 in Polish and English were selected for analysis. Results. In children and adolescents with FASD, the oral hygiene status is unsatisfactory. There is a higher rate of dental caries and more malocclusions compared to the general population. The main ones include Class II malocclusions, crossbites and teeth crowding. Children with FASD have significantly more dysfunctions and parafunctions in the stomatognathic system. Conclusion. Children with FASD should receive institutional preventive and therapeutic care, which will allow for systematic control of the oral health status and malocclusions. (Ludwików K, Zadurska M, Czochrowska E. Dental and orthodontic evaluation of children and adolescents with Foetal Alcohol Spectrum Disorders (FASD) - a review of the literature. Orthod Forum 2021; 17 (3): 237-44).

Received: 30.08 .2021

Accepted: 29.10 .2021

https://doi.org/10.5114/for.2021.11050

Key words: foetal alcohol syndrome, FAS, facial dysmorphia, prenatal foetal alcohol exposure

\section{Introduction}

FASD (Foetal Alcohol Spectrum Disorders) is a term that encompasses many developmental abnormalities resulting from prenatal alcohol exposure, whereas FAS (Foetal Alcohol Syndrome) is its most severe form and accounts for approximately $10 \%$ of all FASD disorders (1). As a separate disease entity, FAS was first described by Lemoine et al. (2), and Jones et al. described full dysmorphic facial features and defined it as foetal alcohol syndrome (3). Clinical features of Foetal Alcohol Syndrome include:

1. head and neck abnormalities, i.e. microcephaly, short neck, low, asymmetrically positioned ears, deformed auricles, low forehead, retrognathia and retrogenia, flat midface, narrow palpebral fissures, widely spaced eyes, epicanthal fold, short and small nose, thin vermilion border of the long upper lip and a smooth philtrum,

2. damage to the central nervous system,

3. reduced height and weight;

4. developmental disorders of the cardiovascular and skeletal systems (3).

Diagnosis of FAS can pose problems due to the heterogeneous nature of the disorder and the need to differentiate dysmorphic features with Williams, Aarskog, Noonan, Dubowitz, Brachmann-DeLange syndromes as well as with maternal phenylketonuria, toluene embryopathy, chromosomal deletion/duplication syndromes, and also 
Dental and orthodontic evaluation of children and adolescents with Foetal Alcohol Spectrum Disorders...

dysmorficznych, m.in. z zespołem Williamsa, Aarskoga, Noonan, Dubowitza, Brachmann-DeLange oraz z fenyloketonurią matczyną, embriopatią toluenową, zespołami delecji/duplikacji chromosomowych oraz braku ujednoliconego systemu rozpoznawania FASD (4). Na świecie funkcjonuje kilka równoległych systemów diagnostycznych. Najszerzej rozpowszechnione są kryteria kanadyjskie, waszyngtoński kwestionariusz czterocyfrowy oraz kryteria opublikowane przez Hoyme (5). Poszczególne ośrodki diagnostyczne na świecie same dokonują wyboru stosowanych kryteriów. Od pewnego czasu w poszczególnych krajach, np. w Niemczech i Australii, dopasowuje się te systemy do lokalnych warunków.

W Polsce funkcjonuje kilka placówek specjalizujących się w pracy z osobami z FASD. W większości z nich zastosowano własny system diagnozy, zwykle, choć w różnym stopniu, oparty na jednym z wymienionych. Z uwagi na rosnące zainteresowanie tematyką FASD wśród polskich specjalistów oraz brak ujednoliconego schematu postępowania obowiązującego w poszczególnych ośrodkach, z inicjatywy Państwowej Agencji Rozwiązywania Problemów Alkoholowych w 2020 roku opracowano wytyczne interdyscyplinarnej grupy polskich specjalistów w celu rozpoznawania spektrum FASD.

Od tej pory w Polsce zaleca się rozróżnienie dwóch podstawowych kategorii diagnostycznych w ramach FASD:

- FAS (w klasyfikacji ICD10 oznaczony kodem Q86.0)

- ND-PAE (Neuro-Developmental Disorders Associated with Prenatal Alcohol Exposure) - zaburzenia neurorozwojowe związane z prenatalną ekspozycją na alkohol.

Diagnoza FASD opiera się na stwierdzeniu:

- prenatalnej ekspozycji na działanie alkoholu

- ograniczenia wzrastania pre- i postnatalnego

- kluczowych cech dysmorficznych twarzy

- zaburzeń neurorozwojowych (5).

Do czasu publikacji wytycznych PARPA terminologia opisująca zaburzenia powstałe w wyniku prenatalnej ekspozycji na alkohol była bardzo zróżnicowana. Nomenklatura dla tego przypadku przez lata ulegała ewolucji, wprowadzono szereg pojęć, takich jak Fas, FASD, pFAS, ARND, FAE, ARBD.

Pomimo istnienia poważnych zaburzeń rozwojowych u chorych z FASD, można wdrożyć różnorodne działania terapeutyczne, które pozwolą doprowadzić do lepszego funkcjonowania dziecka lub nie dopuszczą do powstania zaburzeń wtórnych, takich jak choroby psychiczne, konflikty z prawem lub uzależnienia (1).

Badanie przeprowadzone na zlecenie Agencji przez zespół specjalistów wykazało, że rozpowszechnienie FAS w populacji polskiej jest nie mniejsze niż 4 osoby na 1000 , a wszystkich zaburzeń z grupy FASD - nie mniejsze niż 20 osób na 1000 , co jest zbieżne $\mathrm{w}$ doniesieniami z innych krajów (5, $6,7)$. Jednak nie wszystkie dzieci poddawane są od razu specjalistycznej diagnostyce i dopiero lekarze pediatrzy, psycholodzy, rodzice adopcyjni bądź zastępczy kierują je do ośrodków zajmujących się rozpoznawaniem FASD. due to the lack of a standardised system for FASD diagnosis (4). Currently, there are several parallel diagnostic systems worldwide. The Canadian criteria, the Washington 4-digit diagnostic code, and the criteria published by Hoyme are among the most common (5). Individual diagnostic centres around the world make their own selection which criteria to use. For some time now, individual countries such as Germany and Australia have adapted these systems to their local conditions.

In Poland, several institutions specialise in working with people with FASD. Most of them have been using their own diagnostic system that is, usually, though to varying degrees, based on one of the classifications mentioned above. Due to the growing interest in FASD among Polish specialists and the lack of unified management guidelines that could be used in individual centres, in 2020, as part of the initiative of the State Agency for the Prevention of Alcohol-Related Problems, an interdisciplinary group of Polish specialists developed guidelines for the diagnosis of FASD.

Since that time, in Poland, it has been recommended to distinguish two basic diagnostic categories within FASD:

- FAS (coded Q86.0 in the ICD10 classification)

- ND-PAE (Neuro-Developmental Disorders Associated with Prenatal Alcohol Exposure).

The FASD diagnosis is based on the following criteria:

- prenatal exposure to alcohol

- pre- and postnatal growth limitations

- key dysmorphic facial features

- neurodevelopmental disorders (5).

Until the publication of the PARPA guidelines, the terminology describing disorders resulting from prenatal alcohol exposure varied widely. As a result, the nomenclature for this case has evolved over the years, with several terms introduced such as Fas, FASD, pFAS, ARND, FAE, ARBD.

Although patients with FASD show severe developmental disorders, various therapies can be implemented to improve the child's functioning or prevent the development of secondary disorders such as mental illnesses, conflicts with the law or addictions (1).

The study carried out by the team of specialists ordered by the Agency showed that the prevalence of FAS in the Polish population was not less than 4 persons per 1000 , and of all FASD disorders - not less than 20 persons per 1000 , which is consistent with reports from other countries $(5,6,7)$. However, not all children are immediately offered specialist diagnostics, and it it is only paediatricians, psychologists, adoptive or foster parents who refer them to centres specialising in diagnosing FASD. Furthermore, due to difficulties in diagnosing children with FAS and gathering a representative study group, the state of dental and orthodontic knowledge concerning this syndrome of defects is limited. 
K. Ludwików et al.

W związku z trudnościami w diagnozowaniu dzieci z FAS oraz zgromadzeniem reprezentatywnej grupy badanej stan wiedzy stomatologicznej i ortodontycznej dotyczący tego zespołu wad jest ograniczony.

\section{Cel}

Celem pracy była ocena stanu zdrowia jamy ustnej, występowania wad zgryzu oraz ocena zapotrzebowania na leczenie ortodontyczne u dzieci ze Spektrum Płodowych Zaburzeń Alkoholowych (FASD) na podstawie dostępnego piśmiennictwa.

\section{Materiał i metody}

Przeprowadzono przegląd piśmiennictwa w oparciu o bazy danych: PubMed, Scopus, Dentistry \& Oral Sciences Source, Polska Bibliografia Lekarska, z wykorzystaniem słów kluczowych FAS, fetal alcohol syndrome, facial abnormalities, prenatal alcohol exposure. Do analizy wybrano 35 artykułów z lat 1968-2020 w językach polskim i angielskim.

\section{Dyskusja}

W piśmiennictwie istnieje niewiele publikacji na temat stanu uzębienia i higieny jamy ustnej u dzieci z FASD. Trudności związane z przeprowadzeniem badań w grupie dzieci z FASD są przede wszystkim związane z zebraniem wiarygodnej liczebnie grupy badanej. Dzieci z FASD są najczęściej adoptowane, przebywają w rodzinach zastępczych lub w domach dziecka, co oznacza ich rozproszenie na terenie całego kraju (8).

\section{Próchnica i stan higieny jamy ustnej}

Ludwików i wsp. wśród 10 badanych z pełnoobjawowym FAS zaobserwowali ogniska próchnicowe u 30\%, laki - u 10\%, wypełnienia - u 80\%, pojedyncze braki zębowe - u 30\% (8). Naidoo i wsp. stwierdzili, że u dzieci z FAS występował wysoki odsetek powierzchni zębów pokrytych płytką nazębną (ponad $75 \%$ ) oraz krwawienie przy zgłębnikowaniu (66\% badanych). W powyższym badaniu wskaźnik DMFT (wskaźnik intensywności próchnicy określający zapadalność na próchnicę, Decayed, Missing and Filled Teeth; polski skrót PUWZ) był wyższy od wyniku kontrolnego, choć nie różnił się istotnie statystycznie, a komponent brakujących zębów stanowił największą część wskaźnika w obu grupach (9). Ludwików i wsp. w opisie przypadku pacjentki z zespołem FAS w wieku 17 lat 4 miesięcy zauważyli czynną przetokę ropną przy zębie 11 i skierowali pacjentkę na leczenie endodotyczne oraz instruktaż higieny jamy ustnej (10). Blanck i Lubarsch i wsp. wykazali natomiast znacząco istotne różnice DMFT u dzieci z FAS, w porównaniu z grupą kontrolną (11). Podobnie Da Silva i wsp., którzy u 68 zbadanych dzieci z FASD zauważyli również istotnie wyższy poziom próchnicy, w porównaniu do grupy kontrolnej $97 \%$ vs $64,7 \%$ ) i wskaźnika DMFT (12). Wpływ na uzyskane wyniki mogła mieć dieta dzieci z FAS. Badanie przeprowadzone przez

\section{Aim}

The aim of the study was to assess oral health, the occurrence of malocclusions and the need for orthodontic treatment in children with Foetal Alcohol Spectrum Disorders (FASD) based on the available literature.

\section{Material and methods}

A literature review based on the following databases was conducted: PubMed, Scopus, Dentistry \& Oral Sciences Source, Polish Medical Bibliography, and the following keywords were used: FAS, fetal alcohol syndrome, facial abnormalities, prenatal alcohol exposure. 35 articles from the years 1968-2020 in Polish and English were selected for analysis.

\section{Discussion}

There are only few publications in the literature on the dental status and oral hygiene of children with FASD. The difficulties with conducting research in a group of children with FASD are primarily related to the difficulties associated with the collection of a reliable size of the study group. In addition, children with FASD are most often adopted, in foster care or children's homes, which means they are dispersed across the country (8).

\section{Caries and oral hygiene status}

Ludwików et al. studied a group of 10 subjects with fullblown FAS and observed carious plaques in 30\%, varnishes in $10 \%$, fillings in $80 \%$, single missing teeth in $30 \%$ (8). Naidoo et al. found that children with FAS had a high percentage of plaque-covered tooth surfaces (over 75\%) and bleeding on probing ( $66 \%$ of subjects). In the above study, the DMFT index (caries severity score indicating caries incidence: Decayed, Missing and Filled Teeth) was higher than the control score, although not statistically significantly different, and the missing teeth component accounted for the largest portion of this index in both groups (9). Ludwików et al. in a case report of a female patient with FAS aged 17 years and 4 months noticed an active purulent fistula at tooth 11 and referred her for endodontic treatment and oral hygiene briefing (10). However, Blanck and Lubarsch et al. demonstrated significantly different DMFTs in children with FAS, compared to the control group (11). Similarly, Da Silva et al., who studied 68 children with FASD, also observed significantly higher prevalence of caries, compared to the control group (97\% vs $64.7 \%$ ) and DMFT index was also higher (12). The diet of children with FAS may have affected the results. A study by Amos-Kroohs et al. showed abnormal eating habits in patients with FAS, namely decreased satiety, constant snacking and more meals per day, compared to healthy controls (13). Considering that snacking between meals promotes caries, these abnormal eating behaviours of FAS patients may be the cause of their higher 
Amos-Kroohs i wsp. wykazało nieprawidłowe nawyki żywieniowe u pacjentów z FAS ze zmniejszoną sytością, ciągłym podjadaniem i większą liczbą posiłków dziennie, w porównaniu ze zdrowymi osobami z grupy kontrolnej (13). Biorąc pod uwagę fakt, że podjadanie między posiłkami sprzyja próchnicy, te nieprawidłowe zachowania żywieniowe pacjentów z FAS mogą być przyczyną wyższego wskaźnika DMFT bądź próchnicy. Poradnictwo żywieniowe i dalsze badania dotyczące nawyków żywieniowych u pacjentów z FAS byłyby wskazane w odniesieniu do zdrowia jamy ustnej (13). Da Sliva zauważył także, że w porównaniu z grupą kontrolną dzieci z FASD były znacznie starsze podczas pierwszej wizyty u dentysty i bardziej uzależnione od publicznej opieki dentystycznej (12). Podobnie Ludwików i wsp. podczas rutynowego badania jamy ustnej u pacjentki w wieku 17,4 roku z pełnoobjawowym FAS zauważyli liczne wypełniania zębów stałych materiałem amalgamatowym (10).

\section{Zaburzenia $w$ budowie szkliwa}

W badaniu Church i wsp., którym objęto 22 dzieci, nie odnotowano żadnego przypadku ze zmianą w strukturze szkliwa (14). Podobną sytuację dostrzegli Naidoo i wsp. którzy badaną grupę 90 osób z FAS porównali z grupą kontrolną (9). Natomiast w publikacji Blanck-Lubarsch i wsp. przebadano 30 dzieci z FASD i wykazano znacznie wyższy wskaźnik DDE (Developmental Defects of Enamel) w porównaniu do grupy kontrolnej (11).

\section{Rozszczepy wargi i/lub podniebienia}

Yin i wsp. przeprowadzili metaanalizę 12 publikacji z lat 19502019 dotyczących współzależności występowania FAS z rozszczepem wargi i/lub podniebienia i wskazali na brak istotnej różnicy między matkami pijącymi i niepijącymi w trakcie ciąży a ryzykiem urodzenia dziecka z rozszczepem wargi i/lub podniebienia. Nie znaleźli także dowodów potwierdzających istnienie zależności dawka-odpowiedź między spożyciem alkoholu a wzrostem ryzyka rozszczepu wargi i/lub podniebienia (15). Podobne obserwacje odnotowali Ludwików i wsp., którzy w badanej grupie 10 dzieci z FAS nie stwierdzili żadnego przypadku z izolowanym rozszczepem wargi i/lub podniebienia (8).

\section{Dysfunkcje i parafunkcje}

W badaniu Ludwików i wsp., w którym przebadano 10 dzieci z pełnoobjawowym FAS, zaobserwowano w przeważającej części grupy, tj. u 80\%, nieprawidłowy tor oddychania przez usta. Digitomanię (ssanie palca) oraz obgryzanie paznokci stwierdzono u 70\% badanych (8). Podobnie u Blanck-Lubarsch i wsp. odnotowano znacząco częstsze występowanie nieprawidłowego toru oddychania oraz przedłużone ssanie kciuka i smoczka, w porównaniu z grupą kontrolną (11). Podobne obserwacje odnotowali Ludwików i wsp, którzy u pacjentki z pełnoobjawowym zespołem FAS stwierdzili oddychanie przez usta (10). Oddychanie przez usta zawsze wiąże się z występowaniem zaburzeń zgryzu,
DMFT or caries rates. Therefore, nutritional counselling and further research on dietary habits in patients with FAS in relation to oral health would be recommended (13). Da Sliva also noted that compared to the control group, children with FASD were significantly older at their first dental visit and more dependent on public dental care (12). Similarly, during a routine oral examination of a female patient aged 17.4 years with full-blown FAS Ludwików et al. noted multiple amalgam fillings of permanent teeth (10).

\section{Abnormalities in the enamel structure}

In a study by Church et al. involving 22 children, no cases of an enamel structural abnormality were reported (14). A similar situation was observed by Naidoo et al., who compared a study group of 90 individuals with FAS with a control group (9). In contrast, in their research, Blanck-Lubarsch et al. studied 30 children with FASD and found significantly higher rates of DDE (Developmental Defects of Enamel) compared to the control group (11).

\section{Cleft lip and/or palate}

Yin et al. conducted a meta-analysis of 12 publications from 1950-2019 on the correlation of the occurrence of FAS with cleft lip and/or palate and demonstrated there were no significant differences between mothers who consumed or did not consume alcohol during pregnancy and the risk of having a child with cleft lip and/or palate. They also found no evidence supporting a dose-response relationship between alcohol consumption and an increased risk of cleft lip and/or palate(15). Similar observations were reported by Ludwików et al. who in the study group of 10 children with FAS did not find any cases with isolated cleft lip and/or palate (8).

\section{Dysfunctions and parafunctions}

In the study by Ludwików et al. involving 10 children with full-blown FAS, an abnormal breathing pattern - through the mouth - was observed in the vast majority of the group, i.e. in $80 \%$. Digitomania (finger sucking) and nail-biting were found in $70 \%$ of the subjects (8). Similarly, Blanck-Lubarsch et al. reported significantly higher prevalence of an abnormal breathing pattern and prolonged thumb and pacifier sucking, compared to the control group (11). Similar observations were reported by Ludwików et al., who confirmed mouth breathing in a female patient with full-blown FAS (10). Breathing through the mouth is always associated with the occurrence of malocclusions, while bad habits play a significant role only in some of them, probably because they are less important than other factors associated with the aetiopathogenesis of malocclusions (16). The literature also indicates significantly shorter total sleep time, lower sleep efficiency, and more nocturnal awakenings in children with FASD $(17,18)$. It may suggest a connection with mouth breathing. A dental examination of the joints and muscles was performed on a female patient aged 17 years and 8 
natomiast złe nawyki odgrywają znaczącą rolę tylko w niektórych z nich, prawdopodobnie ze względu na ich mniejsze znaczenie niż inne czynniki związane z etiopatogenezą wad zgryzu (16). W piśmiennictwie stwierdzono także występowanie znacznie krótszego całkowitego czasu snu, niższą wydajność snu i więcej nocnych przebudzeń u dzieci z FASD $(17,18)$. Może to sugerować związek z oddychaniem przez usta. Stomatologiczne badanie stawowo-mięśniowe przeprowadzono u pacjentki w wieku 17 lat i 8 miesięcy przez Ludwików i wsp. metodą analizy miofunkcjonalnej wg Bummana oraz badaniem mięśniowym wg Festy, a także wykonano analizę posturalną (10). Na podstawie wywiadu stwierdzono występowanie u pacjentki parafunkcji w postaci codziennego żucia gumy przez około dwóch godzin oraz bólów głowy okolicy czołowej kilka razy w tygodniu. W wyniku badania stwierdzono silną miopatię, skrócenie poziome i pionowe struktur nadgnykowych oraz wadę postawy ciała. Dodatkowo pacjentka po każdym przywiedzeniu układała żuchwę w innej pozycji, co uniemożliwiało ustalenie rodzaju wady zgryzu, a tym samym postawienie właściwej diagnozy ortodontycznej. Ustalenie powtarzalnej relacji żuchwy do szczęki w centralnej relacji kłykcia w stawie skroniowo-żuchwowym było niemożliwe (10).

\section{Występowanie wad zgryzu}

Badanie ortodontyczne przeprowadzone przez Ludwików obejmowało 10 dzieci (w tym 6 dziewcząt i 4 chłopców) u których zdiagnozowano pełnoobjawowy zespół FAS, a średnia wieku wynosiła 13,9. W badaniu normę zgryzową stwierdzono tylko u 20\% badanych, w płaszczyźnie przednio-tylnej u większości badanych dzieci (70\%) stwierdzono II klasę Angle'a, a u 10\% - III klasę Angle'a.

Powiększony nagryz poziomy i pionowy zaobserwowano odpowiednio u 30\% badanych. Z kolei odwrotny nagryz poziomy występował u 10\% pacjentów, podobnie jak zgryz otwarty przedni zdiagnozowano u 10\% badanych. Wśród zaburzeń w płaszczyźnie poprzecznej zgryz krzyżowy zdiagnozowano aż u 30\% badanych. Przemieszczenie linii pośrodkowej dolnej rozpoznano u 70\% badanych i było to najczęstsze zaburzenie diagnozowane w płaszczyźnie poprzecznej. W odniesieniu do oceny miejsca w łuku zębowym obecność szparowatości stwierdzono u 10\% badanych, natomiast stłoczenie zębów dolnych siecznych - aż u 40\% dzieci (8).

Church i wsp. w grupie 22 osób z FASD potwierdzili częste występowanie nieprawidłowości zgryzowych, ale diagnostyka ortodontyczna była przeprowadzona tylko u 15 badanych. W powyższym badaniu 4 osoby miały stwierdzoną I klasę Angle’a oraz po 6 osób - II i III klasę Angle’a, ponadto istniała duża rozpiętość wieku badanych - od 3 do 26 lat (14). Podobne wyniki zaobserwowali Naidoo i wsp., którzy oceniali występowanie wad zgryzu w grupie 90 dzieci z FAS, ze średnią wieku 8,9. W tym badaniu stwierdzono statystycznie znacząco większe pojawianie się wad zgryzu, w porównaniu do grupy kontrolnej. Najczęściej występującymi anomaliami były stłoczenia months by Ludwików et al. using myofunctional analysis according to Bumman and muscle testing according to Festa, and a postural analysis was also performed (10). Based on the patient's history, she was diagnosed with parafunctions such as daily gum chewing for about two hours and frontal headaches several times a week. The examination revealed severe myopathy, horizontal and vertical shortening of the suprahyoid structures, and a postural defect. In addition, the patient placed the mandible in a different position after each adduction, which made it impossible to determine the type of malocclusion and thus to make a correct orthodontic diagnosis. It was impossible to establish a reproducible maxillo-mandibular relation in the centric condylar relation at the temporomandibular joint (10).

\section{Presence of malocclusions}

The orthodontic study conducted by Ludwików included 10 children ( 6 girls and 4 boys) diagnosed with full-blown FAS syndrome, with the mean age of 13.9. In the study, normal occlusion was found only in $20 \%$ of the study children; in the anteroposterior plane, Angle class II was found in most of the study children (70\%), and Angle class III in 10\%.

Increased overbite and overjet were observed in $30 \%$ of the subjects, respectively. On the other hand, reversed overjet was present in $10 \%$ of the patients, and anterior open bite was diagnosed in $10 \%$ of the subjects. Among the transverse plane disorders, crossbite was diagnosed in as many as $30 \%$ of the subjects. A deviated lower midline was observed in $70 \%$ subjects, and it was the most common transverse discrepancy. With regard to the assessment of space in the dental arch, the presence of gaps was found in $10 \%$ of the study children, while crowding of lower incisors - in as many as $40 \%$ of children (8).

In a group of 22 subjects with FASD, Church et al. confirmed the frequent occurrence of malocclusions, but the orthodontic diagnosis was performed only in 15 subjects. In this study, 4 subjects had Angle class I and Angle class II and III were found in 6 subjects each. Moreover, the age range was wide - from 3 to 26 years (14). Similar results were observed by Naidoo et al. who evaluated the prevalence of malocclusions in a group of 90 children with FAS, with the mean age of 8.9. In this study, the occurrence of malocclusions was found to be statistically significantly higher compared to the control group. The most common anomalies included incisor crowding, increased overjet, and open bite, but no classification of malocclusions was performed (9). The study by Blanck-Lubrsch et al. which included a group of 30 children shows a significantly higher increase in malocclusions in patients with FASD, compared to controls, and especially a higher incidence of crossbites (19). The authors used PAR (Peer Assesment Rating Index), developed by Richmond et al., as a high-reliability index to assess the severity of malocclusions and compare treatment outcomes (20). In a case report of a female patient with FAS, 
siekaczy, zwiększony nagryz poziomy i zgryz otwarty, ale nie przeprowadzono klasyfikacji wad zgryzu (9). Wyniki znacznie zwiększonego wzrostu wad zgryzu u pacjentów z FASD, w porównaniu z grupą kontrolną, a zwłaszcza częstszego występowania zgryzów krzyżowych, obserwujemy w badaniu Blanck-Lubrsch i wsp., które objęło grupę 30 dzieci (19). Autorzy skorzystali ze wskaźnika PAR, czyli Wskaźnika Oceny Porównawczej (Peer Assesment Rating Index), jako wskaźnika wysokiej wiarygodności do oceny stopnia zaawansowania wad zgryzu oraz porównywania wyników leczenia, który został opracowany przez Richmond i wsp. (20). U Ludwików i wsp. w opisie przypadku pacjentki z FAS zauważono także w badaniu wewnątrzustnym obecność zgryzu krzyżowego bocznego lewostronnego oraz stłoczenia zębów w łuku górnym i dolnym (10). Dodatkową ocenę stanu jamy ustnej przeprowadzili Blanck-Lubarsch i wsp., którzy pobrali wyciski szczęki za pomocą masy alginatowej u 30 dzieci z zespołem FAS ze średnią wieku 8 lat i 8 miesięcy. Na dalszym etapie badania za pomocą skanera ocenili głębokość podniebienia, która nie wykazała statystycznie istotnych różnic pomiędzy grupą dzieci z FAS a grupą kontrolną (21). Także Blanck-Lubarsch wykorzystali skaner w badaniu zewnątrzustnym wśród 30 pacjentów z FAS. Badania wykazały istotnie znaczące różnice w profilu dzieci z FAS, u których częściej odnotowano profil retrogantyczny oraz skrócenie środkowego i wydłużenie dolnego piętra twarzy (21). Natomiast wskaźnik asymetrii twarzy nie różnił się istotnie (22). Nie stwierdzono także istotnej różnicy między dziećmi z FAS a grupą kontrolną w pomiarach szerokości ust oraz w pomiarach szerokości skrzydełek nosa (23). Natomiast stwierdzono istotne różnice w odległości między prawą i lewą rynienką nosa oraz długością prawej i lewej szpary powiekowej (23). Dodatkowo Blanck-Lubarsch wskazuje, że głębokość rynienki nosa jest znacznie zmniejszona u dzieci z FAS (24). Warto zaznaczyć, że metody skanowania twarzy 3D, w przeciwieństwie do oceny wizualnej, umożliwiają bardziej obiektywną ocenę ilościową, a tym samym mogą dostarczyć dodatkowych dowodów w diagnostyce FAS.

\section{Wnioski}

U dzieci z FASD zwraca uwagę gorsza higiena jamy ustnej, częstsze występowanie dysfunkcji i parafunkcji układu stomatognatycznego, a szczególnie oddychanie przez usta. Występowanie wad zgryzu wśród dzieci i młodzieży z FAS było częstsze w porównaniu z populacją ogólną. Najczęściej obserwowano występowanie różnych postaci zgryzów krzyżowych oraz stłoczeń zębów, a także wad dotylnych, co świadczy o większej potrzebie leczenia ortodontycznego w tej grupie badanych w porównaniu do populacji ogólnej. Dlatego wskazane jest przeprowadzanie wczesnej diagnostyki screeningowej w kierunku występowania dysfunkcji i parafunkcji u pacjentów z FASD w odniesieniu do profilaktyki wad zgryzu oraz objęcie tej grupy dzieci instytucjonalną opieką stomatologiczną i ortodontyczną.
Ludwików et al. also noted the presence of left lateral crossbite and teeth crowding in the upper and lower arch during an intraoral examination (10). Blanck-Lubarsch et al. conducted an additional assessment of the oral health status and took maxillary impressions using alginate in 30 children with FAS with the mean age of 8 years and 8 months. At a further stage of the study, they used a scanner to assess the depth of the palate, and no statistically significant differences between the group of children with FAS and the control group were observed (21). Blanck-Lubarsch also used the scanner during an extraoral examination among 30 patients with FAS. Studies demonstrated significant differences in the profile of children with FAS, as they were more likely to have a retrognathic profile, and moreover, shortening of the midface and lengthening of the lower face were observed (21). In contrast, the facial asymmetry index was not significantly different (22). There were also no significant differences between children with FAS and controls in measurements of the mouth width and in measurements of the nasal ala width (23). However, significant differences were found in the distance between the right and left nasal groove and the length of the right and left palpebral fissure (23). Additionally, Blanck-Lubarsch indicate that the philtrum depth is significantly reduced in children with FAS (24). It is worth noting that 3D facial scanning methods, as opposed to visual assessments, allow for a more objective quantitative assessment and thus may provide additional evidence in the diagnosis of FAS.

\section{Conclusions}

Children with FASD have poorer oral hygiene, more frequent dysfunctions and parafunctions of the stomatognathic system, especially such as mouth breathing. The prevalence of malocclusions among children and adolescents with FAS was higher compared to the general population. Various forms of crossbites and teeth crowding, as well as posterior defects were most frequently observed, and it indicates a greater need for orthodontic treatment in this group of patients compared to the general population. Therefore, it is advisable to perform early screening diagnostics for the occurrence of dysfunctions and parafunctions in patients with FASD with respect to malocclusion prophylaxis and to extend institutional dental and orthodontic care to this group of children. 


\section{Piśmiennictwo / References}

1. Banach M. Alkoholowy zespół płodu Teoria Diagnoza Praktyka. WAM 2011: 118-268.

2. Lemoine P, Harousseau H, Borteyru JP, Menuet JC. Les enfants des parents alcooliques: anomalies observees apropos de 127 cas. Ouest Medical 1968; 21: 476-82.

3. Jones KL, Smith DW. Recognition of the fetal alcohol syndrome in early infancy. Lancet 1973; 302: 999-1001.

4. Astley SJ. Diagnostic guide for fetal alcohol spectrum disorders the 4-digit diagnostic code third edition. University of Washington 2004 .

5. Okulicz-Kozaryn K, Szymańska K, Maryniak A, Dyląg A, Śmigiel R, Helwich E, Domin A, Borkowska M i wsp. Rozpoznawanie spektrum płodowych zaburzeń alkoholowych. Zalecenia opracowane przez interdyscyplinarny zespół polskich ekspertów. Medycyna praktyczna. Pediatria 2020; 1: 1-44.

6. Chavez GF, Cordero JF, Becerra JE. Leading major congenital malformations among minority groups in the United States, 19811986. MMWR Morb Mortal Wkly Rep 1988; 37: 17-24.

7. Sampson PD, Streissguth AP, Bookstein FL, Little RE, Clarren SK, Dehaene P, Hanson JW, Graham JM Jr. Incidence of fetal alcohol syndrome and prevalence of alcohol-related neurodevelopmental disorder. Teratology 1997; 56: 317-26.

8. Ludwików K, Zadurska M, Czochrowska E. Występowanie wad zgryzu u dzieci w wieku rozwojowym z Alkoholowym Zespołem Płodowym (FAS) badanie pilotażowe. Edentico 2019; 2: 84-91.

9. Naidoo S, Chikte U, Laubscher R, Lombard C. Fetal alcohol syndrome: anthropometric and oral health status. J Contemp Dent Pract 2005; 6: 101-5.

10. Ludwików K, Sędkiewicz J, Obłoj B. Dental and Facial Characteristics of a Patient with Fetal Alcohol Syndrome - Case Report. Dent Med Prob 2015; 4: 505-11.

11. Blanck-Lubarsch M, Dirksen D, Feldmann R, Sauerland C, Hohoff A. Tooth malformations, DMFT index, speech impairment and oral habits in patients with fetal alcohol syndrome. Int J Environ Res Public Health 2019; 16: 4401.

12. Da Silva K, Wood D. The oral health status and treatment needs of children with fetal alcohol spectrum disorder. Clin Oral Investig 2021; 25: 3497-503.
13. Amos-Kroohs RM, Fink BA, Smith CJ, Chin L, Van Calcar SC, Wozniak JR, Smith SM. Abnormal Eating Behaviors Are Common in Children with Fetal Alcohol Spectrum Disorder. J Pediatr 2016; 169: 194-200.

14. Church MW, Eldis F, Blakley BW, Bawle EV. Hearing, Language, Speech, Vestibular, and Dentofacial Disorders in Fetal Alcohol Syndrome. Alcohol Clin Exp Res 1997; 21: 227-37.

15. Yin X, Li J, Li Y, Zou S. Maternal alcohol consumption and oral clefts: a meta-analysis. Br J Oral Maxillofac Surg 2019; 57: 839-46.

16. Grippaudo C, Paolantonio EG, Antonini G, Saulle R, La Torre G, Deli R. Association between oral habits, mouth breathing and malocclusion. Acta Ital 2016; 36: 386-94.

17. Mughal R, Hill CM, Joyce A, Dimitriou D. Sleep and Cognition in Children with Fetal Alcohol Spectrum Disorders (FASD) and Children with Autism Spectrum Disorders (ASD). Brain Sci 2020; 10: 863.

18. Wengel T, Hanlon-Dearman AC, Fjeldsted B. Sleep and sensory characteristics in young children with fetal alcohol spectrum disorder. J Dev Behav Pediatr 2011; 32: 384-92.

19. Blanck-Lubarsch M, Flieger S, Feldmann R, Kirschneck C, Sauerland C, Hohoff A. Malocclusion can give additional hints for diagnosis of fetal alcohol spectrum disorder. Alcohol Alcohol 2019; 54: 56-61.

20. Richmond S, Shaw WC, O'Brian KD. The development ot the PAR Index (Peer Assessment Rating): reliability abd validity. Eur J Orthod 1992; 14: 125-39.

21. Blanck-Lubarsch M, Dirksen D, Feldmann R, Sauerland C, Hohoff A. Children with Fetal Alcohol Syndrome (FAS): 3D-Analysis of Palatal Depth and 3D-Metric Facial Length. Int J Environ Res Public Health 2019; 21: 95.

22. Blanck-Lubarsch M, Dirksen D, Feldmann R, Sauerland C, Kirschneck C, Hohoff A. Asymmetry-index and orthodontic facial analysis of children with foetal alcohol syndrome using 3D-facial scans. Pediatr Res 2020; 88: 243-9.

23. Blanck-Lubarsch M, Dirksen D, Feldmann R, Sauerland C, Hohoff A. 3D-Analysis of Mouth, Nose and Eye Parameters in Children with Fetal Alcohol Syndrome (FAS). Int J Environ Res Public Health 2019; 16: 2535.

24. Blanck-Lubarsch M, Dirksen D, Feldmann R, Sauerland C, Kirschneck C, Hohoff A. 3D Analysis of Philtrum Depth in Children with Fetal Alcohol Syndrome. Alcohol Alcohol 2019; 54: 152-8. 